\title{
RESEARCH
}

Open Access

\section{Do the diversity of plants and sulphur application influence the population fluctuation of insect predator?}

\author{
Mohamed Ahmed Gesraha* (D), Amany Ramadan Ebeid and Atef Abd El-Rahman Ali
}

\begin{abstract}
Background: Numerous predatory insects were recorded on different plants; some were fed on the floral nectar and others as visitors. Other insects used any plant as a shelter or associated with their prey. Pollinators and beneficial arthropods suffering from a wide range of chemical pesticides are used. So, seeking for safer alternatives is mandatory to conserve such beneficial arthropods. Sorell-98\% is a sulphur formulation which was examined against some insect predators with minimal adverse impacts.
\end{abstract}

Method: Agricultural Sorell-98\% (commercial Sulphur formulation) was applied to protect many crops against some plant diseases and sucking insect pests (aphis, whiteflies, thrips) and mite pests as well. This formulation was applied at a rate of $30 \mathrm{~kg} /$ Feddan after 30 days of plantation. Two rectangular areas (ca. $700 \mathrm{~m}^{2}$ each) were chosen to execute experiments. The first area was in a field which was sown with marrow plant, while the second was in an okra field. Each area was partitioned into four equal plots (ca. $75 \mathrm{~m}^{2}$ ). Similar plots (third area) were done but received no treatments (second control area). Examination of the mean numbers of the natural enemies was recorded at several intervals and was achieved at $7 \mathrm{am}$. Samples of 50 plants were inspected-on spot-per plot/ time interval in the three experimental zones. The mean number of each predator/time interval and percentage of increase and/or decrease was calculated.

Results: Results reveal that the abundance of the target predators was affected indirectly in different cultivated plants after sulphur application, as a result of different plant nature and consequently the population of pests invaded. At all inspection periods, it was observed that the mean numbers and abundance of adult predators on marrow plants was more than that reported in an okra field. Under all inspection times, there was a significant difference between the mean numbers of recorded predators, where Coccinella adults recorded the highest mean numbers, followed by Chrysoperla adults. Stethorus adults recorded the least mean number, either before or after sulphur application.

Conclusion: The abundance of any arthropod predators is closely related with their favourable insect prey and did not relate to a certain plant by itself. The three tested adult predators were-to some extent-affliction from the sulphur application.

Keywords: Sulphur formulation, Okra, Marrow, Chrysoperla carnea, Coccinella undicempunctata, Stethorus punctillium

\footnotetext{
* Correspondence: mgesraha@gmail.com

Pests and Plant Protection Department, National Research Centre, Dokki, Cairo, Egypt
} 


\section{Background}

The application of synthetic pesticides has caused a threat to non-target organisms and the environment due to their overuse (Savary et al. 2006). Since the release of xenobiotic results in the increase of environmental risk, the goal should be to use such compounds carefully so that they cause the least negative impact on the environment (Savary et al. 2012) into which they are released. To remove harmful effects on the non-target organisms, encapsulation of the active ingredient with other materials such as a polymer can allow sensitive ingredients to be physically enveloped into a protective matrix in order to protect core materials from adverse reactions due to factors like air or light (Madhuban et al. 2012).

Several studies have shown negative effects of sulphur on natural enemies including predators, parasitoids, and predatory mites. Sulphur as a natural material and its commercial formulations are now using to control many plant diseases and some piercing-sucking insect pests

Numerous predatory and parasitoid insects were recorded on different plants, and many of them fed on the exposed floral nectar; others used any plant as a shelter or were associated with their prey (Bugg et al. 1987, Finch and Collier 2000, Sunderland and Samu 2000).

Pollinators and beneficial arthropods suffering from the wide range of chemical pesticides are used (Cohen et al. 1996; Araya et al. 1997b; Kumar and Singh 2002; Newman et al. 2004; Linda 2012). Seeking for safer alternatives is mandatory to conserve these beneficial arthropods. Several studies have shown the negative effects of sulphur application on natural enemies including parasitoids, predatory mites, and spiders (Martinson et al. 2001; Gent et al. 2009; Nash et al. 2010).

Sulphur as a natural material and its commercial formulations as well are now used to control many plant diseases, insect pests, and some piercing-sucking insect pests (Cohen et al. 1996; Araya et al. 1997a, b; Kumar and Singh 2002, Biondi et al., 2012).

Many sulphur formulations were applied to protect plants and to control some insect pests (Wetzel and Dickler 1994; Newman et al. 2004). Sorell-98\% is one of the sulphur formulation which was applied according to the Egyptian Ministry of Agriculture recommendations. This formulation was examined against some insect predators with minimal adverse impacts toward these tested natural enemies (Matter et al. 2018 and Matter et al. 2019, Gesraha and Ebeid 2019).

This work is to investigate the following: (1) Do diversity of plants influence the population fluctuation of the three tested insect predators? (2) How far are these two different tested factors in combination with the tested formulation induced adverse effects on the density and abundance of the three natural enemies, Coccinella undecimpunctata, Chrysoperla carnae, and Stethorus punctillium naturally existing in fields of okra (Hibiscus esculentus L.) and marrow (Cucurbita pepo L.)?

\section{Methods}

1- Randomized complete block design was applied for this experiment.

2- Sorell-98\% (trade name of Sulphur formulation) was manufactured by Kafr El-Zayat Co. and was applied in okra and marrow fields at the rate of $30 \mathrm{~kg} /$ Feddan 30 days post plantation against some plant diseases (rusts, mildew, powdery mildew, etc) and sucking insect pests (whiteflies, leafhoppers, aphids, plant bugs) and mites.

3- Dusting of sulphur was carried out using Chapin 5000 16-Ounce Hand Rose and Plant Duster Sprayer - Model \#5000 duster 30 days post sowing.

4- Field experiments were carried out (as described by Gesraha and Ebeid 2019 and Matter et al. 2018, 2019) in two separate fields already planted, one for marrow and the other for okra plants in Manawat village, at Giza Governorate. All agricultural practices were carried out as usual. Just before sulphur formulation was applied (as Ministry of Agriculture recommendations), two rectangular sections (ca. $700 \mathrm{~m}^{2}$ each) were chosen in each field. Each section was divided longitudinally into two equivalent parts (first part of them for treatment and the second part as a control adjacent to the treated one), each of them comprises six rows, and each part was partitioned into four plots about $75 \mathrm{~m}^{2}$ each. Similar plots (third area) were prepared, but no treatments were made (second control area). Surveying the mean numbers of the objective natural enemies in the target territories was recorded at several intervals (just before dusting, 2, 12, 24, 48, and 72 hours and 7 days post application) was accomplished early in the morning (7 am). Samples of 50 plants were inspected-on spot-per plot per time interval in the three tested zones. The average number of each natural enemy/ time interval and the percentage of increase and/or decrease were calculated.

\section{Statistical analysis}

MSTAT-C Statistical Package (Freed, 1985) Computer program was used. Analysis of variance (ANOVA) F-test was applied. Randomized complete block design for factor A, with factor B as a split plot on A and factor $\mathrm{C}$ as a split plot on B. Least significant difference test (LSD) was carried out for mean differentiation.

Factorial ANOVA for the factors is as follows:

- Factor A (Var 1: plant) with values from 1 to 2 
- Factor B (Var 2: predators) with values from 1 to 3

- Factor C (Var 3: treatment) with values from 1 to 3

- Replication (Var 4: replicates) with values from 1 to 4

\section{Results}

Data in Table 1 reveal that-in case of tested factor A (tested plants) - the abundance of the target predators was affected with different cultivated plants after sulphur application $(0 \mathrm{~h})$, that is a direct result of the idea of the plant and consequently the population of pests invaded. At all inspection times, it was observed that the abundance of adult predators on Marrow plants was more than that reported in the okra field. The same result was observed at all inspection times (Table 1).

In the case of time effect post application, the target predators were affected with sulphur application (Table 1) factor B (predators), it was observed that, under all inspection times, there was a significant difference between the mean numbers of recorded predators, where Stethorus predator recorded the least mean number, either before or after sulphur application, indicating that this predator was scarce or more susceptible to sulphur application than the others. Chrysoperla adults' mean numbers were ranked the second. Lastly, Coccinella adults recorded the highest mean number of adults, almost at all inspection intervals (Table 1).

As for factor $\mathrm{C}$ (plot treatments), examining the reaction of adult predators towards sulphur application, the mean number of adults recorded at treated plots was significantly lower than that for control plots, except that recoded at $0 \mathrm{~h}$. Statistically, there was insignificant difference between them (Table 1). In addition, it was observed that at 2 and $168 \mathrm{~h}$ post application, a significant difference between the mean numbers of recorded adults for the three treatments was occurred, where the other inspection intervals clarify that insignificant difference exists between untreated plots of the first and second area (Table 1).

Regarding to the interaction (Plants*Predators) effects of the chosen plants upon the tested predator's abundance after sulphur application (Table 2), significant differences were observed at all inspection periods between the mean numbers of the target predators. Generally, marrow field attains the highest mean number of adult predators than that of okra. The higher mean number of adults lacewing achieved in marrow field across all inspection time followed by Coccinella adults either in Marrow or Okra

Table 1 Mean numbers of the abundance of the tested adult predators related to three examined factors

\begin{tabular}{|c|c|c|c|c|c|c|c|}
\hline & \multicolumn{7}{|c|}{ Post treatment intervals (hours) } \\
\hline & $\mathrm{Oh}$ & $2 \mathrm{~h}$ & $12 \mathrm{~h}$ & $24 \mathrm{~h}$ & $48 h$ & $72 \mathrm{~h}$ & $168 \mathrm{~h}$ \\
\hline & \multicolumn{7}{|c|}{ Mean number of predators \pm SE } \\
\hline \multicolumn{8}{|l|}{ Plant } \\
\hline Okra & $7.42 \pm 0.73^{b}$ & $4.14 \pm 0.53^{b}$ & $7.58 \pm 1.16^{b}$ & $7.33 \pm 1.09^{b}$ & $8.81 \pm 1.02^{b}$ & $8.58 \pm 0.94^{b}$ & $9.69 \pm 0.93^{b}$ \\
\hline Marrow & $13.36 \pm 1.06^{\mathrm{a}}$ & $12.50 \pm 1.71^{\mathrm{a}}$ & $14.56 \pm 1.86^{\mathrm{a}}$ & $15.64 \pm 2.03^{\mathrm{a}}$ & $14.83 \pm 1.57^{\mathrm{a}}$ & $13.44 \pm 1.25^{\mathrm{a}}$ & $13.50 \pm 1.44^{a}$ \\
\hline Fvalue & $141.346^{* *}$ & $338.484^{* *}$ & $77.619^{* *}$ & $2506.570^{* *}$ & $29.315^{* *}$ & $18.161^{*}$ & $45.593^{* *}$ \\
\hline$P$ value & 0.0013 & 0.0004 & 0.0031 & 0.0000 & 0.0124 & 0.0237 & 0.0066 \\
\hline \multicolumn{8}{|l|}{ Predators (B) } \\
\hline Coccinella & $13.58 \pm 0.95^{a}$ & $10.29 \pm 1.59^{a}$ & $15.46 \pm 1.72^{a}$ & $15.79 \pm 1.83^{a}$ & $16.25 \pm 1.63^{a}$ & $15.63 \pm 1.03^{a}$ & $16.46 \pm 1.17^{a}$ \\
\hline Chrysoperla & $11.46 \pm 1.55^{\mathrm{b}}$ & $11.38 \pm 2.26^{a}$ & $12.71 \pm 2.53^{b}$ & $14.38 \pm 2.64^{a}$ & $13.25 \pm 1.89^{\mathrm{b}}$ & $12.04 \pm 1.57^{b}$ & $12.58 \pm 1.70^{b}$ \\
\hline Stethorus & $6.13 \pm 0.59 c$ & $3.29 \pm 0.49^{b}$ & $5.04 \pm 0.82^{c}$ & $4.29 \pm 0.79^{b}$ & $5.96 \pm 0.70^{c}$ & $5.38 \pm 0.66^{c}$ & $5.75 \pm 0.62^{c}$ \\
\hline Fvalue & $24.899 * *$ & $100.812^{* *}$ & $52.092^{* *}$ & $180.713^{* *}$ & $48.931^{* *}$ & $132.578^{* *}$ & $61.030^{* *}$ \\
\hline LSD at $5 \%$ & 2.373 & 1.346 & 2.305 & 1.437 & 2.332 & 1.392 & 2.138 \\
\hline$P$ value & 0.0001 & 0.0000 & 0.0000 & 0.0000 & 0.0000 & 0.0000 & 0.0000 \\
\hline \multicolumn{8}{|l|}{ Treatments } \\
\hline Control & $10.13 \pm 1.25^{a}$ & $9.08 \pm 1.33^{b}$ & $14.67 \pm 1.80^{a}$ & $14.54 \pm 2.01^{a}$ & $13.88 \pm 1.79^{a}$ & $13.25 \pm 1.56^{\mathrm{a}}$ & $14.04 \pm 1.81^{a}$ \\
\hline Sulphur treated & $11.13 \pm 1.29^{a}$ & $3.46 \pm 0.76^{c}$ & $3.92 \pm 0.80^{b}$ & $5.04 \pm 0.92^{b}$ & $7.46 \pm 1.04^{b}$ & $7.75 \pm 1.05^{b}$ & $8.88 \pm 1.21^{c}$ \\
\hline Untreated second area & $9.92 \pm 1.29^{a}$ & $12.42 \pm 2.33^{\mathrm{a}}$ & $14.63 \pm 2.31^{a}$ & $14.88 \pm 2.60^{a}$ & $14.13 \pm 1.91^{\mathrm{a}}$ & $12.04 \pm 1.44^{\mathrm{a}}$ & $11.88 \pm 1.37^{b}$ \\
\hline Fvalue & $1.169^{N S}$ & $85.637^{* *}$ & $234.577^{* *}$ & $101.773^{* *}$ & $32.172^{* *}$ & $38.261^{* *}$ & $18.493^{* *}$ \\
\hline LSD at $5 \%$ & - & 1.403 & 1.160 & 1.587 & 1.911 & 1.340 & 1.730 \\
\hline$P$ value & 0.3221 & 0.0000 & 0.0000 & 0.0000 & 0.0000 & 0.0000 & 0.0000 \\
\hline
\end{tabular}

Means in a column followed with the same letter(s) are not significantly different ( $P$ at $5 \%)$ 
Table 2 Interaction of two factors (Plant*Predator) with respect to the adult predators abundance

\begin{tabular}{|c|c|c|c|c|c|c|c|c|}
\hline \multirow{2}{*}{\multicolumn{2}{|c|}{ Plant*Predator }} & \multicolumn{7}{|c|}{ Post treatment intervals (hours) } \\
\hline & & $\overline{\mathrm{Oh}}$ & $2 \mathrm{~h}$ & $12 \mathrm{~h}$ & $24 \mathrm{~h}$ & $48 \mathrm{~h}$ & $72 \mathrm{~h}$ & $168 \mathrm{~h}$ \\
\hline & & \multicolumn{7}{|c|}{ Mean number of each predator \pm SE } \\
\hline \multirow[t]{3}{*}{ Okra } & Coccinella & $11.83 \pm 1.30^{c}$ & $6.33 \pm 0.99^{c}$ & $14.42 \pm 2.14^{b}$ & $13.83 \pm 1.96^{c}$ & $15.25 \pm 1.79^{b}$ & $14.92 \pm 1.32^{\mathrm{b}}$ & $15.42 \pm 1.62^{a}$ \\
\hline & Chrysoperla & $4.17 \pm 0.17^{d}$ & $2.75 \pm 0.69^{d}$ & $3.25 \pm 0.62^{c}$ & $3.58 \pm 0.31^{d}$ & $5.17 \pm 0.35^{c}$ & $5.83 \pm 0.37^{c}$ & $7.58 \pm 0.34^{b}$ \\
\hline & Stethorus & $6.25 \pm 0.71^{d}$ & $3.33 \pm 0.75^{d}$ & $5.08 \pm 1.16^{c}$ & $4.58 \pm 1.28^{d}$ & $6.00 \pm 0.99^{c}$ & $5.00 \pm 0.99^{c}$ & $6.08 \pm 0.97^{b}$ \\
\hline \multirow[t]{3}{*}{ Marrow } & Coccinella & $15.33 \pm 1.23^{b}$ & $14.25 \pm 2.59^{b}$ & $16.50 \pm 2.75^{b}$ & $17.75 \pm 3.08^{b}$ & $17.25 \pm 2.79^{b}$ & $16.33 \pm 1.61^{\mathrm{ab}}$ & $17.50 \pm 1.69^{\mathrm{a}}$ \\
\hline & Chrysoperla & $18.75 \pm 0.55^{a}$ & $20.00 \pm 2.72^{a}$ & $22.17 \pm 3.18^{\mathrm{a}}$ & $25.17 \pm 2.79^{a}$ & $21.33 \pm 1.73^{\mathrm{a}}$ & $18.25 \pm 1.78^{\mathrm{a}}$ & $17.58 \pm 2.73^{\mathrm{a}}$ \\
\hline & Stethorus & $6.00 \pm 0.96^{d}$ & $3.25 \pm 0.66^{d}$ & $5.00 \pm 1.19^{c}$ & $5.92 \pm 0.98^{d}$ & $5.92 \pm 1.02^{c}$ & $5.75 \pm 0.91^{c}$ & $5.42 \pm 0.79^{b}$ \\
\hline \multicolumn{2}{|l|}{$F$ value } & $25.080^{* *}$ & $98.521^{* *}$ & $48.343^{* *}$ & $157.734^{* *}$ & $34.139^{* *}$ & $52.582^{* *}$ & $15.918^{* *}$ \\
\hline \multicolumn{2}{|c|}{ LSD at $5 \%$} & 3.356 & 1.904 & 3.259 & 2.033 & 3.297 & 1.969 & 3.024 \\
\hline \multicolumn{2}{|l|}{$P$ value } & 0.0001 & 0.0000 & 0.0000 & 0.0000 & 0.0000 & 0.0000 & 0.0004 \\
\hline
\end{tabular}

Means in a column followed with the same letter(s) are not significantly different $(P$ at $5 \%)$

**Highly significant

fields. Stethorus adults recorded the lowest mean number under both examined plants (Table 2).

As for the interaction (Plants*Treatments) between the tested plants and treated and untreated plots on the abundance of examined predators adults, it was found that almost all inspection interval achieved significant differences except that of $0 \mathrm{~h}$ (before application) and $168 \mathrm{~h}$ (1 week post application) where insignificant differences were recorded (Table 3). On another view, the mean number of recorded adults at the untreated second zone was higher than that of others, and those recorded from the marrow fields, in general, was higher than that of okra fields across all inspection intervals (Table 3).

Data illustrated in Table 4 shows the impact of interaction effects of sulphur treatments on the abundance of the tested adult predators (Predators*Treatments). It was noticed that all inspection intervals achieved significant differences between the mean numbers of adult predators, except that for 0-h interval, as usual, which was insignificant $(F=0.960)$. Generally, Stethorus recorded the most minimal mean number of adults, which was statistically negligible, regardless of the mean numbers of the other two predators for the three assessed plots.

Almost in all inspection intervals, Coccinella adults recorded the highest mean numbers, pursued by lacewing adults. Moreover, the untreated second territories recorded the most remarkable number of adults, especially in the case of Coccinella adults, then followed by the untreated plots adjacent to the treated one (control) then treated plots, which were recorded the lowest mean numbers of adult predators (Table 4).

Regarding the interaction effects between all factors together (Plants*Predators*Treatments) and their impact on the adult predators'abundance, data could be summarized

Table 3 Interaction of two factors (Plant*Treatment) with respect to the adult predators' abundance

\begin{tabular}{|c|c|c|c|c|c|c|c|c|}
\hline \multirow{2}{*}{\multicolumn{2}{|c|}{ Plant*Treatment }} & \multicolumn{7}{|c|}{ Post treatment intervals (hours) } \\
\hline & & $\mathrm{Oh}$ & $2 \mathrm{~h}$ & $12 \mathrm{~h}$ & $24 \mathrm{~h}$ & $48 \mathrm{~h}$ & $72 \mathrm{~h}$ & $168 \mathrm{~h}$ \\
\hline & & \multicolumn{7}{|c|}{ Mean number of predators \pm SE } \\
\hline \multirow[t]{3}{*}{ Okra } & Control & $7.08 \pm 1.25^{\mathrm{a}}$ & $5.83 \pm 0.77^{c}$ & $12.08 \pm 2.39^{c}$ & $11.08 \pm 2.49^{c}$ & $10.92 \pm 2.02^{b}$ & $10.67 \pm 1.76^{b}$ & $11.17 \pm 1.73^{\mathrm{a}}$ \\
\hline & Sulphur treated & $8.67 \pm 1.48^{\mathrm{a}}$ & $1.58 \pm 0.72^{d}$ & $3.08 \pm 1.19^{f}$ & $3.58 \pm 0.86^{\mathrm{e}}$ & $5.67 \pm 0.99^{c}$ & $6.25 \pm 1.29^{c}$ & $8.00 \pm 1.73^{\mathrm{a}}$ \\
\hline & Untreated second area & $5.60 \pm 0.94^{\mathrm{a}}$ & $5.00 \pm 0.68^{c}$ & $7.58 \pm 0.76^{d}$ & $7.33 \pm 0.80^{d}$ & $9.83 \pm 0.99^{b}$ & $8.83 \pm 0.71^{b}$ & $9.92 \pm 0.91^{\mathrm{a}}$ \\
\hline \multirow[t]{3}{*}{ Marrow } & Control & $13.17 \pm 1.82^{\mathrm{a}}$ & $12.33 \pm 2.21^{\mathrm{b}}$ & $17.25 \pm 2.58^{\mathrm{b}}$ & $18.00 \pm 2.92^{b}$ & $16.83 \pm 2.77^{a}$ & $15.83 \pm 2.41^{\mathrm{a}}$ & $16.92 \pm 3.02^{\mathrm{a}}$ \\
\hline & Sulphur treated & $13.58 \pm 1.91^{\mathrm{a}}$ & $5.33 \pm 1.13^{c}$ & $4.75 \pm 1.07^{e}$ & $6.50 \pm 1.55^{d}$ & $9.25 \pm 1.72^{b}$ & $9.25 \pm 1.59^{b}$ & $9.75 \pm 1.73^{\mathrm{a}}$ \\
\hline & Untreated second area & $13.33 \pm 1.92^{\mathrm{a}}$ & $19.83 \pm 3.47^{\mathrm{a}}$ & $21.67 \pm 3.34^{\mathrm{a}}$ & $22.42 \pm 0.80^{\mathrm{a}}$ & $18.42 \pm 3.99^{\mathrm{a}}$ & $15.25 \pm 2.02^{\mathrm{a}}$ & $13.83 \pm 2.32^{\mathrm{a}}$ \\
\hline \multicolumn{2}{|l|}{$F$ value } & $0.654^{\mathrm{NS}}$ & $34.784^{* *}$ & $62.643^{* *}$ & $31.383^{* *}$ & $3.525^{*}$ & $3.421^{*}$ & $2.754^{\mathrm{NS}}$ \\
\hline \multicolumn{2}{|c|}{ LSD at $5 \%$} & - & 1.985 & 1.641 & 2.245 & 2.702 & 1.895 & - \\
\hline \multicolumn{2}{|l|}{$P$ value } & - & 0.0000 & 0.0000 & 0.0000 & 0.0400 & 0.0436 & - \\
\hline
\end{tabular}

Means in a column followed with the same letter(s) are not significantly different ( $P$ at 5\%)

*Significant

**Highly significant

NS Insignificant 
Table 4 Interaction two factors (Predator*Treatment) with respect to the adult predators' abundance

\begin{tabular}{|c|c|c|c|c|c|c|c|c|}
\hline \multirow{2}{*}{\multicolumn{2}{|c|}{ Predator*Treatment }} & \multicolumn{7}{|c|}{ Post treatment intervals (hours) } \\
\hline & & $\mathrm{Oh}$ & $2 \mathrm{~h}$ & $12 \mathrm{~h}$ & $24 \mathrm{~h}$ & $48 \mathrm{~h}$ & $72 \mathrm{~h}$ & $168 \mathrm{~h}$ \\
\hline & & \multicolumn{7}{|c|}{ Mean number of each predator $\pm \mathrm{SE}$} \\
\hline \multirow[t]{3}{*}{ Coccinella } & Control & $12.38 \pm 1.54^{\mathrm{a}}$ & $9.50 \pm 1.00^{c}$ & $18.63 \pm 2.21^{\mathrm{ab}}$ & $19.13 \pm 1.47^{\mathrm{ab}}$ & $16.63 \pm 1.78^{b}$ & $16.25 \pm 1.03^{b}$ & $15.63 \pm 1.72^{b}$ \\
\hline & Sulphur treated & $15.38 \pm 1.78^{\mathrm{a}}$ & $4.75 \pm 1.33^{d}$ & $7.50 \pm 0.82^{c d}$ & $6.63 \pm 0.80^{c d}$ & $9.75 \pm 0.77^{\mathrm{cd}}$ & $11.75 \pm 0.68^{c}$ & $14.00 \pm 1.99^{b}$ \\
\hline & Untreated second area & $13.00 \pm 1.61^{\mathrm{a}}$ & $16.63 \pm 3.45^{\mathrm{a}}$ & $20.25 \pm 3.11^{\mathrm{a}}$ & $21.63 \pm 3.43^{\mathrm{a}}$ & $22.38 \pm 3.33^{\mathrm{a}}$ & $18.88 \pm 2.29^{\mathrm{a}}$ & $19.75 \pm 1.99^{\mathrm{a}}$ \\
\hline \multirow[t]{3}{*}{ Chrysoperla } & Control & $11.50 \pm 2.96^{\mathrm{a}}$ & $13.25 \pm 3.18^{b}$ & $16.63 \pm 4.32^{b}$ & $16.63 \pm 5.08^{b}$ & $16.75 \pm 4.56^{b}$ & $16.38 \pm 3.77^{b}$ & $18.63 \pm 4.42^{\mathrm{a}}$ \\
\hline & Sulphur treated & $11.25 \pm 2.58^{\mathrm{a}}$ & $4.38 \pm 1.64^{d}$ & $4.13 \pm 1.32^{\mathrm{e}}$ & $7.75 \pm 1.91^{c}$ & $10.25 \pm 2.05^{\mathrm{cd}}$ & $9.88 \pm 1.42^{c}$ & $10.13 \pm 0.61^{c}$ \\
\hline & Untreated second area & $11.63 \pm 2.85^{\mathrm{a}}$ & $16.50 \pm 5.14^{\mathrm{a}}$ & $17.38 \pm 5.18^{b}$ & $18.75 \pm 5.42^{b}$ & $12.75 \pm 2.70^{c}$ & $9.88 \pm 2.01^{c}$ & $9.00 \pm 0.89^{c d}$ \\
\hline \multirow[t]{3}{*}{ Stethorus } & Control & $6.50 \pm 1.18^{\mathrm{a}}$ & $4.50 \pm 0.87^{d}$ & $8.75 \pm 0.82^{c}$ & $7.88 \pm 1.38^{c}$ & $8.25 \pm 0.86^{d}$ & $7.13 \pm 0.77^{d}$ & $7.88 \pm 0.95^{\mathrm{cd}}$ \\
\hline & Sulphur treated & $6.75 \pm 1.11^{\mathrm{a}}$ & $1.25 \pm 0.49^{e}$ & $0.13 \pm 0.13^{f}$ & $0.75 \pm 0.16^{\mathrm{e}}$ & $2.38 \pm 0.57^{\mathrm{e}}$ & $1.63 \pm 0.26^{\mathrm{e}}$ & $2.50 \pm 0.57^{e}$ \\
\hline & Untreated second area & $5.13 \pm 0.72^{\mathrm{a}}$ & $4.13 \pm 0.69^{d}$ & $6.25 \pm 0.49^{d}$ & $4.25 \pm 0.77^{d}$ & $7.25 \pm 94^{d}$ & $7.38 \pm 0.82^{d}$ & $6.88 \pm 0.44^{d}$ \\
\hline \multicolumn{2}{|l|}{$F$ value } & $0.960^{\mathrm{NS}}$ & $11.679^{* *}$ & $8.287^{* *}$ & $9.682^{* *}$ & $6.662^{* *}$ & $9.591^{* *}$ & $11.198^{* *}$ \\
\hline \multicolumn{2}{|l|}{ LSD at $5 \%$} & - & 2.431 & 2.009 & 2.750 & 3.310 & 2.321 & 2.997 \\
\hline \multicolumn{2}{|l|}{$P$ value } & - & 0.0000 & 0.0001 & 0.0000 & 0.0004 & 0.0000 & 0.0000 \\
\hline
\end{tabular}

Means in a column followed with the same letter(s) are not significantly different $(P$ at $5 \%)$ **Highly significant

${ }^{N S}$ Insignificant

in Table 5. As frequent of this experiment, 0-h interval exhibit insignificant differences $(F=0.668)$ between tested factors and mean numbers of recorded adult predators. While all other check-up intervals reflect significant differences between the abundance of adult predators' according to the tested factors.

Although there were some differences between the recorded mean numbers of adult predators at 0-h interval, but these differences were statistically insignificant (Table 5).

Otherwise, the rest of all inspection period intervals exhibited highly significant difference between predators abundance as a result of all examined factors together. Generally, marrow fields comprised the highest mean number of adult predators, where Chrysoperla ranked the first, and Coccinella was the second, while Stethorus was ranked third, which record the least mean numbers (Table 5).

After 2, 12, and $24 \mathrm{~h}$ of sulphur application, the mean numbers of Chrysoperla adults recorded was the highest in untreated second area plots. Then after 48, 72, and $168 \mathrm{~h}$ additionally, the recorded mean number was the most elevated at untreated plots contiguous the treated one.

Adults of C. undicempunctata records the most superior mean numbers just at 24 and $48 \mathrm{~h}$ post treatment for the second untreated region of marrow field.

Generally, marrow field comprised higher mean numbers of the target predators than okra field. The mean numbers of Chrysoperla in marrow field ranged between 15.50 and 33.00 individuals, while Coccinella ranged from 25.50 to 30.00 individuals, across all inspection periods. The corresponding figure for okra field ranged from 0.25 to 8.75 and 3.25 to 22.25 individuals, for
Chrysoperla and Coccinella, respectively. Stethorus adults' mean numbers were ranged between 0.00 to 8.75 and 0.25 to 8.75 individuals for marrow and okra fields, respectively (Table 5). From the abovementioned data, it was observed that Coccinella adults were more abundance for either marrow or okra fields throughout our experiment, regardless of different tested factors, followed by Chrysoperla while Stethorus adults nearly were the same (Table 5).

In other view, Table 5 showed that the highest recorded mean number ["a" green colour] was recorded in untreated second area and control plots, especially in marrow field for Chrysoperla throughout almost all inspection intervals; then followed by the recorded mean number ["b" yellow colour] for untreated second area for Coccinella in marrow field too. Then the recorded mean number for Coccinella (21.25 and 16.50 at 24 and $48 \mathrm{~h}$ post treatment, respectively). After that, most of all recorded numbers were somewhat near to each other throughout all inspection intervals.

On the other side, Stethorus recorded the least mean numbers when compared with the two other predators in all treated and/or untreated plots throughout all inspection intervals either in okra or marrow fields.

\section{Discussion}

The present work shed light on sulphur application impacts upon the three important predators, which were naturally prevailing in okra and marrow fields. The differences in the recorded mean numbers of adult predators not only referred to sulphur application, but also to the many other factors (Ali et al. 2007; Al-Dahawi et al. 


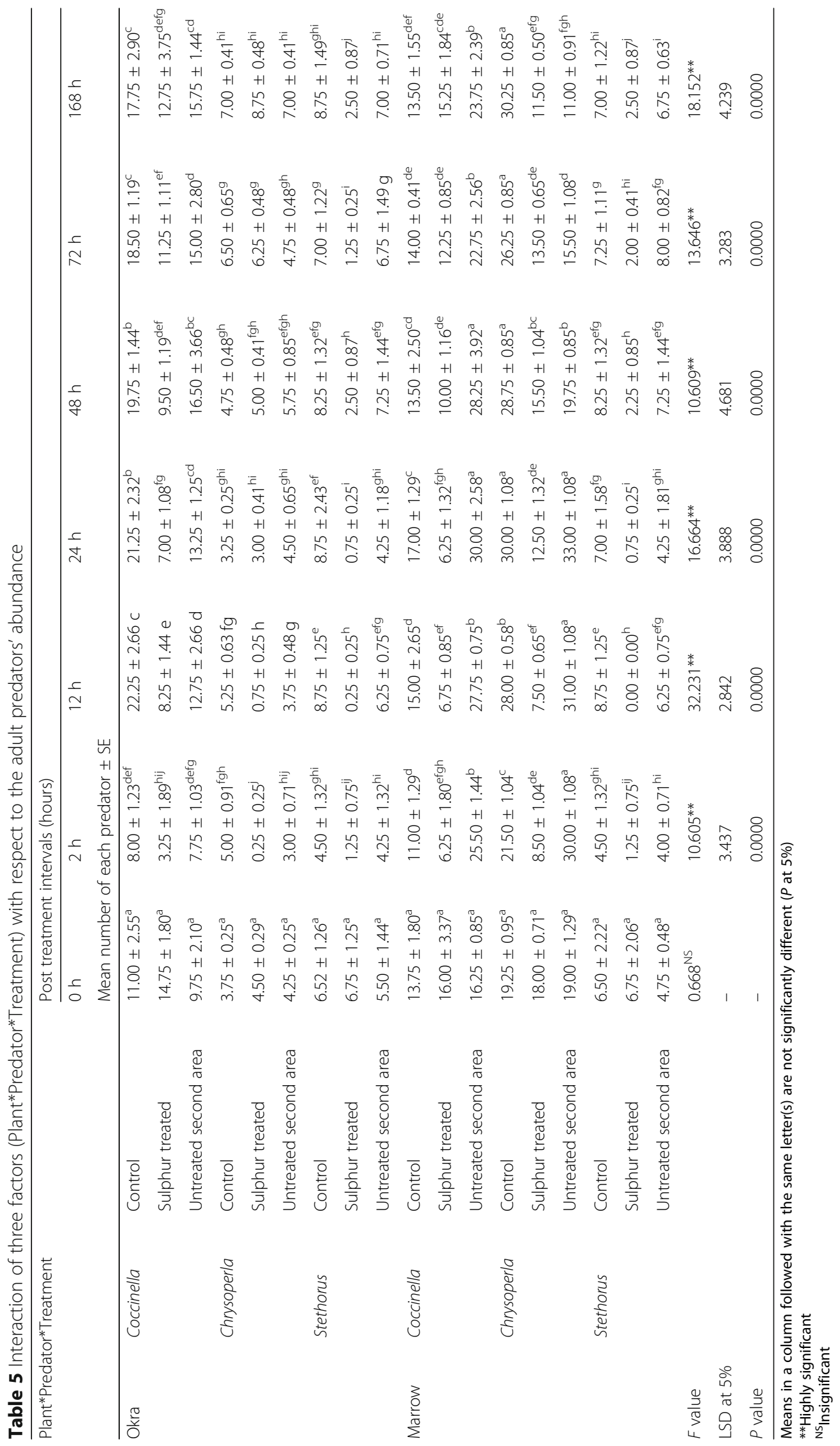


2010; Haddad et al. 2009, 2011; Johnson et al. 2006, 2009; Schmitz 2006). They reported that the developmental stage of insect pests and the elements of the leaf contents and its concentrations are responsible for making a certain plant more favourable than another for insect pests feeding, and these findings were in accordance with our results about the diverse predator mean numbers prevailing in okra and/or marrow plants as associated predators of different insect pests.

In addition, our results about the abundance of predators adults on either okra or marrow plants were partially matched with that reported by Mooney and Agrawal (2008) when they work on Milkweed genotype; they mentioned that little information is known about the mechanisms by which plant genotype configure the arthropod community structure. They referred that to many different factors including pest species, climatic conditions, the associated predatory arthropods existing, the plant age, and lastly plant sap and its favourability by insect pest for feeding, consequently the abundance of its associated predatory arthropod.

Our findings matched with Chakraborty et al. (2014) and Bhatt et al. (2018) on their survey on okra fields. They mentioned that there was a diversity of insect pests and their predators, naturally occurring. These predators are belonging to different Orders especially Coleopteran, Orthoptera, Neuroptera Lepidoptera, Hemiptera, and Dictyoptera.

Our results revealed that the three examined adult predators were somewhat suffering from the sulphur application. Adult predators escaping from treated plants into other clean plants are either adjacent to the treated plots or moves to other far plants. This result was in agreement with that reported by Matter et al. (2018, 2019) and Gesraha and Ebeid (2019).

In addition, results explain that the difference between the sprayed tested plants was significantly affected by the mean numbers of the recorded predatory adults. Where marrow plant was heavily invaded by different insect and/or mite pests consequently comprised a large number of different examined predators, these findings agreed with that reported by Matter et al. $(2018,2019)$ and Gesraha and Ebeid (2019).

\section{Conclusion}

It could be concluded that the abundance of any arthropod predators is strongly associated with their preferable insect pest (prey) and did not relate to a certain plant by itself (Tables 3 and 5). The three tested adult predators were-to some extent-suffering from the sulphur application as shown in Tables 3, 4, and 5. It was obvious that adult predators escaping from treated plants into other clean plants are either adjacent to the treated plots or travel to other plants to avoid the adverse effect of sulphur formulation, i.e. sulphur formulation act as repellents for the tested adult predators. In addition, sulphur formulation may be toxic for the adult predators if it contacts them. Adult predators start to return back again after different periods according to its capability to resist the sulphur residues and re-established once more.

We recommended that sulphur (in any formulation) must be applied with high restrictions, either as fertilizer or as a pesticide, to preserve the wildlife of arthropod pollinators and mites and/or insect predators.

\section{Acknowledgements \\ The authors are profoundly appreciative of Prof.।Dr. Matter, M.M.; Late Prof.\Dr. Farag, N.A. for their profitable exhorts, and much obliged for all schools, particularly for Mr. Hussein S.H., specialized right hand, Pests and Plant Protection Department, National Research Center, for the help they gave.}

\section{Significant statement}

This study is important to keep the environment clean and free of chemical insecticide pollution as much as possible, exhibit the role of new resources from locally available materials safe, easy preparing, cheap, possible to utilize in combination with other biological control method of IPM program, and decrease build up resistance strains of the insect.

\section{Authors' contributions}

ARE collected the publications needed, shared in constructing the tables and interpreting the results, edited the manuscript, and revised the final form. AAA shared in executing field experiments, collected the specimens, and gathered data and publications needed. MAG carried out the statistical analysis, interpreted the analyzed data, obtained the results, constructed the tables, and edited the manuscript. All authors read and approved the final manuscript.

\section{Funding}

This work was personally funded by the authors.

\section{Availability of data and materials}

All datasets which were abstracted of the study have been drawn and are presented in the main manuscript. All tables have not been published anywhere else before. All data and materials are available.

Ethics approval and consent to participate Not applicable

\section{Consent for publication}

Not applicable

\section{Competing interests}

The authors declare that they have no competing interests.

Received: 5 April 2019 Accepted: 21 September 2019

Published online: 21 November 2019

\section{References}

Al-Dahawi SSJ, Ali AA, Sameer SH (2010) The influence of some nutritional and biochemical characters of three cotton cultivars on the two spotted spider mites Tetranychus urticae Koch and the predators Stethorus gilvifrons (Muls.) and Scolothrips sexmaculatus (Pergs.). Anbar J Agric Sci 8(4):379-389 ISSN: 1992-7479. Website: http://www.ajas.uoanbar.edu.iq

Ali AA, Morad SS, Mohammed JK, Ajeel IF (2007) Response of some introduced and locally improved wheat and barley cultivars to infestation by three important insect pests in Ninava Province, North of Iraq. Anbar J. Agric. Sci, 5(1): 251-266. Website:http://www.ajas.uoanbar.edu.iq

Araya C, Arretz VP, Guerrero SMA, Lamborot CL (1997a) Observation of Polistes buyssoni (Brethes) (Hymeniptera: Vrspidae), predator of Rachiplusia nu (Guenee) (Lepidoptera: Noctuidae) larvae on field beans in the metropolitan region., Chile. c 17(1/2):19-23. 
Araya JE, Arretz VP, Lamborot CL, Guerrero SMA (1997b) Natural control by predators of Rachiplusia nu (Guenee) (Lepidoptera: Noctuidae) on Phaseolus beans in Central Chile. Z Pflanzenk Pflanzen 104:147-152

Bhatt B, Joshi S, Karnatak AK (2018) Biodiversity of insect pests and their predators on okra agroecosystem. J Pharmacogn Phytochem 7(4):84-86

Biondi A, Urbaneja A, Zappalà L, Siscaro G, Mollá O (2012) Efficacy of sulphur on Tuta absoluta and its side effects on the predator Nesidiocoris tenuis. J Appl Entomol 136:401-409

Bugg RL, Ehler LE, Wilson LT (1987) Effect of Common Knotweed (Polygonum aviculare) on Abundance and Efficiency of Insect Predators of Crop Pests. HILGARDIA 55(7):1-51

Chakraborty A, Kumar K, Rajadurai G (2014) Biodiversity of insect fauna in okra (Abelmoschus esculentus (L.) Moench)) Ecosystem. Trends in Biosciences 7(16): 2206-2211, 2014

Cohen H, Horowrrz AR, Nestel D, Rosen D (1996) Susceptibility of the woolly apple aphid parasitoid, Aphelinus mali (Hym.: Aphelinidae), to common pesticides used in apple orchards in Israel. Entomophaga 41(2):225-233

Finch S, Collier RH (2000) Host-plant selection by insects - a theory based on 'appropriate/inappropriate landings' by pest insects of cruciferous plants. Entomol Exp Appl 96:91-102

Freed RD (1985) MSTAT-C Statistical Package, Version 2.0.0. Crop and Soil Science Department, Michigan State University, East Lansing

Gent DH, James DG, Wright LC, Brooks DJ, Barbour JD, Dreves AJ, Fisher GC, Walton VM (2009) Effects of powdery mildew fungicide programs on twospotted spider mite (Acari: Tetranychidae), hop aphid (Hemiptera: Aphididae), and their natural enemies in hop yards. Econ Entomol 102:274-286

Gesraha MA, Ebeid AR (2019) Impact of Sulphur dust application on the abundance of two important coccinellid predators in Marrow fields. Bull Nat Res Cent Egypt 43(34):1-7

Haddad NM, Crutsinger GM, Gross K, Haarstad J, Knops JMH, Tilman D (2009) Plant species loss decreases arthropod diversity and shifts trophic structure. Ecology Letters 12:1029-1039

Haddad NM, Crutsinger GM, Gross K, Haarstad J, Tilman D (2011) Plant diversity and the stability of foodwebs. Ecology Letters 14:42-46

Johnson MTJ, Lajeunesse MJ, Agrawal AA (2006) Additive and interactive effects of plant genotypic diversity on arthropod communities and plant fitness. Ecology Letters 9:24-34

Johnson MTJ, Vellend M, Stinchcombe JR (2009) Evolution in plant populations as a driver of ecological changes in arthropod communities. Phil Trans R Soc B 364:1593-1605

Kumar PS, Singh SP (2002) Wettable sulphur is toxic to Hirsutella thompsonii, the most important natural enemy of the coconut mite. Indian Coconut Journal. Coconut Dev Board Kochi India 33(1):1-2

Linda T (2012) Pesticide impacts on beneficial species- Fact Sheet. Available: www.mvwi.com.au/items/511/2012-05-FS-Pesticide-Impacts2.pdf

Madhuban G, Rajesh K, Arunava G (2012) Nano-pesticides - A recent approach for pest control. JPPS 4(2):1-7

Martinson T, Williams L III, English-Loeb G (2001) Compatibility of chemical disease and insect management practices used in New York vineyards with biological control by Anagrus spp. (Hymenoptera: Mymaridae), parasitoids of Erythroneura leafhoppers. Biol Control 22:227-234

Matter MM, Ali AA, Marei SS, El-Fandary OO, Farag NA, Gesraha MA (2018) Impact of the application of sulphur formulation on the abundance and activity of insect predators naturally existing in marrow fields. Asian J Biol 7(1):1-8

Matter MM, Ebeid AR, Marei SS, El-Fandary OO, Farag NA, Gesraha MA (2019) Effect of sulphur dust application on some insect predators naturally occurringin Okra fields. Bioscience Research 16(2):1153-1160

Mooney KA, Agrawal AA (2008) Plant genotype shapes ant-aphid interactions: implications for community structure and indirect plant defense. Am Nat 171(6):E195-E205

Nash MA, Hoffmann AA, Thomson LJ (2010) Identifying signature of chemical applications on indigenous and invasive nontarget arthropod communities in vineyards. Ecol Appl 20:1693-1703

Newman IC, Walker JTS, Rogers DJ (2004) Mortality of the leafroller parasitoid Dolichogenidae tasmanica (Hym.: Braconidae) exposed to orchard pesticide residues. N Z Plant Prot 57:8-12

Savary S, Horgan F, Willocquet L, Heong KL (2012) A review of principles for sustainable pest management in rice. Crop Protection 32:54-63

Savary S, Teng PS, Willocquet L Nutter Jr FW. (2006) Quantification and modeling of crop losses: a review of purposes. Annual Review of Phytopathology 44:89-12
Schmitz OJ (2006) Predators have large effects on ecosystem properties by changing plant diversity, not plant biomass. Ecology 87(6):1432-1437

Sunderland K, Samu F (2000) Effects of agricultural diversification on the abundance, distribution, and pest control potential of spiders: a review. Entomol Exp Appl 95:1-13

Wetzel C, Dickler E (1994) Side effects of sulphur and natural pyrethroid on Trichrogramma dendrolimi Matsumura (Hym., Trichogrammatidae) in apple orchards. Bull OILB/SROP 17(10):123-131

\section{Publisher's Note}

Springer Nature remains neutral with regard to jurisdictional claims in published maps and institutional affiliations.

\section{Submit your manuscript to a SpringerOpen ${ }^{\circ}$ journal and benefit from:}

- Convenient online submission

- Rigorous peer review

- Open access: articles freely available online

High visibility within the field

- Retaining the copyright to your article

Submit your next manuscript at $\boldsymbol{\nabla}$ springeropen.com 